\title{
Front Matter: Volume 8797
}

, "Front Matter: Volume 8797," Proc. SPIE 8797, Advanced Microscopy Techniques III, 879701 (25 June 2013); doi: 10.1117/12.2034041

SPIE. Event: European Conferences on Biomedical Optics, 2013, Munich, Germany 


\title{
PROGRESS IN BIOMEDICAL OPTICS AND IMAGING
}

\section{Advanced Microscopy Techniques III}

\author{
Emmanuel Beaurepaire \\ Peter T. C. So \\ Editors
}

\section{5-16 May 2013 \\ Munich, Germany}

Sponsored by

The Optical Society (United States)

SPIE

With Support from

Air Force Office of Scientific Research (United States)

ThorLabs (United Kingdom)

Student Award Sponsors

Toptica Photonics AG (Germany)

Zeiss (United States)

Published by

SPIE 
The papers included in this volume were part of the technical conference cited on the cover and title page. Papers were selected and subject to review by the editors and conference program committee. Some conference presentations may not be available for publication. The papers published in these proceedings reflect the work and thoughts of the authors and are published herein as submitted. The publisher is not responsible for the validity of the information or for any outcomes resulting from reliance thereon.

Please use the following format to cite material from this book:

Author(s), "Title of Paper," in Advanced Microscopy Techniques III, edited by Emmanuel Beaurepaire, Peter T. C. So, Proc. of OSA Biomedical Optics-SPIE Vol. 8797 (SPIE, Bellingham, WA, 2013) Article CID Number.

ISSN: 1605-7422

ISBN: 9780819496461

Copublished by

SPIE

P.O. Box 10, Bellingham, Washington 98227-0010 USA

Telephone +1 3606763290 (Pacific Time) · Fax +1 3606471445

SPIE.org

and

The Optical Society

2010 Massachusetts Ave., N.W., Washington, D.C., 20036 USA

Telephone 1 202/223-8130 (Eastern Time) · Fax 1 202/223-1096

http://www.osa.org

Copyright (C) 2013, Society of Photo-Optical Instrumentation Engineers and The Optical Society

Copying of material in this book for internal or personal use, or for the internal or personal use of specific clients, beyond the fair use provisions granted by the U.S. Copyright Law is authorized by SPIE subject to payment of copying fees. The Transactional Reporting Service base fee for this volume is $\$ 18.00$ per article (or portion thereof), which should be paid directly to the Copyright Clearance Center (CCC), 222 Rosewood Drive, Danvers, MA 01923. Payment may also be made electronically through CCC Online at copyright.com. Other copying for republication, resale, advertising or promotion, or any form of systematic or multiple reproduction of any material in this book is prohibited except with permission in writing from the publisher. The CCC fee code is $1605-7422 / 13 / \$ 18.00$.

Printed in the United States of America.

Publication of record for individual papers is online in the SPIE Digital Library.

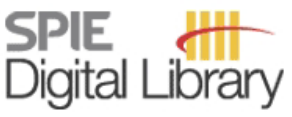

SPIEDigitalLibrary.org

Paper Numbering: Proceedings of SPIE follow an e-First publication model, with papers published first online and then in print and on CD-ROM. Papers are published as they are submitted and meet publication criteria. A unique, consistent, permanent citation identifier (CID) number is assigned to each article at the time of the first publication. Utilization of CIDs allows articles to be fully citable as soon as they are published online, and connects the same identifier to all online, print, and electronic versions of the publication. SPIE uses a six-digit CID article numbering system in which:

- The first four digits correspond to the SPIE volume number.

- The last two digits indicate publication order within the volume using a Base 36 numbering

system employing both numerals and letters. These two-number sets start with 00, 01, 02, 03, 04, $05,06,07,08,09,0 A, 0 B \ldots 0 Z$, followed by 10-1Z, 20-2Z, etc.

The CID Number appears on each page of the manuscript. The complete citation is used on the first page, and an abbreviated version on subsequent pages. Numbers in the index correspond to the last two digits of the six-digit CID Number. 


\section{Contents}

vii Conference Committee

BIOMEDICAL APPLICATIONS I

879702 Quantification of inflammation in colonic tissue sections and wound healing in-vitro with digital holographic microscopy [8797-13]

D. Bettenworth, P. Lenz, P. Krausewitz, M. Brückner, Univ. Hospital of Muenster (Germany); S. Ketelhut, G. von Bally, Univ. of Muenster (Germany); D. Domagk, B. Kemper, Univ. Hospital of Muenster (Germany)

879703 Techniques for 3D tracking of single molecules with nanometer accuracy in living cells [8797-14]

L. Gardini, LENS, European Lab. for Non-linear Spectroscopy (Italy); M. Capitanio, LENS, European Lab. for Non-linear Spectroscopy (Italy) and Univ. of Florence (Italy);

F. S. Pavone, LENS, European Lab. for Non-linear Spectroscopy (Italy) and Univ. of Florence (Italy) and National Institute of Optics, National Research Council (Italy) and International Ctr. Of Computational Neurophotonics (Italy)

879704 Changes induced by peripheral nerve injury in the morphology and nanomechanics of sensory neurons [8797-10]

O. Benzina, Lab. Charles Coulomb, CNRS, Univ. Montpellier 2 (France) and Lab. LVBPPE, Ctr. de Biotechnologie de Sfax (Tunisia); V. Szabo, Lab. Charles Coulomb, CNRS, Univ. Montpellier 2 (France); O. Lucas, INSERM (France); M. Saab, T. Cloitre, Lab. Charles Coulomb, CNRS, Univ. Montpellier 2 (France); F. Scamps, INSERM (France); C. Gergely, M. Martin, Lab. Charles Coulomb, CNRS, Univ. Montpellier 2 (France)

879705 Multiphoton intravital microscopy setup to visualize the mouse mammary gland [8797-6] J. Adur, Univ. Estadual de Campinas (Brazil) and National Univ. of Entre Ríos (Argentina); A. M. Herrera Torres, CES Univ. (Colombia) and Univ Estadual de Campinas (Brazil); A. Masedunskas, M. O. Baratti, National Institute of Science and Technology on Photonics Applied to Cell Biology (Brazil); A. A. de Thomaz, Univ. Estadual de Campinas (Brazil); V. B. Pelegati, National Institute of Science and Technology on Photonics Applied to Cell Biology (Brazil); H. F. Carvalho, C. L. Cesar, Univ. Estadual de Campinas (Brazil) and National Institute of Science and Technology on Photonics Applied to Cell Biology (Brazil) 
879706 Scanning laser optical tomography: a highly efficient volumetric imaging technique for mesoscopic specimens [8797-5]

H. Meyer, Laser Zentrum Hannover e.V. (Germany) and Hanover Medical School

(Germany); G. Antonopoulos, M. Heidrich, R.-A. Lorbeer, Laser Zentrum Hannover e.V.

(Germany); M. Kellner, Hanover Medical School (Germany); A. Winkel, Hanover Medical

School (Germany) and CrossBIT - Network Ctr. for Biocompatibility and Implant

Immunology in Medical (Germany); M. Stiesch, CrossBIT - Network Ctr. for Biocompatibility and Implant Immunology in Medical (Germany); M. P. Kühnel, M. Ochs, Hanover Medical

School (Germany); T. Ripken, Laser Zentrum Hannover e.V. (Germany)

\section{SHG/THG/CARS/SRS I}

879707 Polarization-resolved SHG microscopy of rat-tail tendon with controlled mechanical strain [8797-21]

I. Gusachenko, Y. Goulam Houssen, Lab. for Optics and Biosciences, CNRS, Ecole

Polytechnique (France); V. Tran, J.-M. Allain, Solid Mechanics Lab., CNRS, Ecole

Polytechnique (France); M.-C. Schanne-Klein, Lab. for Optics and Biosciences, CNRS, Ecole

Polytechnique (France)

\section{FLUORESCENCE II}

879708 Dual mode fibre bundle confocal endomicroscopy: combining reflectance and fluorescence imaging [8797-18]

M. Hughes, V. Simaiaki, T. P. Chang, G.-Z. Yang, Imperial College London (United Kingdom)

879709 Improving TCSPC data acquisition from CMOS SPAD arrays [8797-25]

N. Krstajić, The Univ. of Edinburgh (United Kingdom); S. Poland, King's College London

(United Kingdom); D. Tyndall, Dialog Semiconductor Ltd. (United Kingdom); R. Walker, The Univ. of Edinburgh (United Kingdom); S. Coelho, King's College London (United Kingdom);

D. D.-U. Li, Univ. of Sussex (United Kingdom); J. Richardson, Dialog Semiconductor Ltd.

(United Kingdom); S. Ameer-Beg, King's College London (United Kingdom); R. Henderson,

The Univ. of Edinburgh (United Kingdom)

PHASE I

8797 OA High resolution quantitative phase imaging in digital holographic microscopy by modulated object illumination with an electrically focusable lens [8797-11]

B. Kemper, R. Schubert, A. Vollmer, Univ. of Muenster (Germany)

OPTICAL METROLOGY I: JOINT SESSION WITH OPTICAL METROLOGY

8797 OB Low-cost miniature fiber-optic extrinsic Fabry-Perot interferometric pressure sensor for biomedical applications [8797-3]

S. Poeggel, D. Tosi, G. Leen, E. Lewis, Univ. of Limerick (Ireland)

iv 
8797 OC Force-clamp laser trapping of rapidly interacting molecules [8797-7]

M. Capitanio, LENS, European Lab. for Non-linear Spectroscopy (Italy) and Univ. of Florence (Italy); C. Monico, LENS, European Lab. for Non-linear Spectroscopy (Italy); F. Vanzi, LENS, European Lab. for Non-linear Spectroscopy (Italy) and Univ. of Florence (Italy); F. S. Pavone, LENS, European Lab. for Non-linear Spectroscopy (Italy) and Univ. of Florence (Italy) and National Institute of Optics, National Research Council (Italy) and International Ctr. Of Computational Neurophotonics (Italy)

\section{SHG/THG/CARS/SRS II}

8797 OD Characterization of atherosclerotic arterial tissue using multimodal non-linear optical microscopy [8797-2]

R. Cicchi, National Institute of Optics, National Research Council (Italy) and LENS, European Lab. for Non-linear Spectroscopy (Italy); C. Matthäus, T. Meyer, Institute of Photonic Technology (Germany); A. Lattermann, Jena Univ. Hospital, Friedrich-Schiller-Univ. (Germany); B. Dietzek, Institute of Photonic Technology (Germany) and Friedrich Schiller Univ. Jena (Germany); B. R. Brehm, Catholic Clinic - Koblenz (Germany); J. Popp, Institute of Photonic Technology (Germany) and Friedrich Schiller Univ. Jena (Germany); F. S. Pavone, LENS, European Lab. for Non-linear Spectroscopy (Italy) and National Institute of Optics, National Research Council (Italy) and Univ. of Florences (Italy)

$8797 \mathrm{OE}$ CARS and non-linear microscopy imaging of brain tumors [8797-4]

R. Galli, O. Uckermann, S. Tamosaityte, K. Geiger, G. Schackert, G. Steiner, E. Koch, M. Kirsch, Carl Gustav Carus Univ. Hospital, Dresden Univ. of Technology (Germany)

BIOMEDICAL APPLICATIONS II

8797 OF Ultrafast force-clamp spectroscopy to probe lac repressor-DNA interactions (Invited Paper) [8797-17]

C. Monico, LENS, European Lab. for Non-linear Spectroscopy (Italy); M. Capitanio, LENS, European Lab. for Non-linear Spectroscopy (Italy) and Univ. of Florence (Italy); G. Belcastro, LENS, European Lab. for Non-linear Spectroscopy (Italy); F. Vanzi, LENS, European Lab. for Non-linear Spectroscopy (Italy) and Univ. of Florence (Italy); F. S. Pavone, LENS, European Lab. for Non-linear Spectroscopy (Italy) and Univ. of Florence (Italy) and National Institute of Optics, National Research council, Florence (Italy) and National Institute of Optics, National Research Council (Italy) and International Ctr. Of Computational Neurophotonics (Italy)

8797 OG Neural plasticity explored by correlative two-photon and electron/SPIM microscopy [8797-15]

A. L. Allegra Mascaro, L. Silvestri, I. Costantini, LENS, European Lab. for Non-linear Spectroscopy (Italy); L. Sacconi, LENS, European Lab. for Non-linear Spectroscopy (Italy) and International Ctr. Of Computational Neurophotonics (Italy); B. Maco, G. W. Knott, Ecole Polytechnique Fédérale de Lausanne (Switzerland); F. S. Pavone, LENS, European Lab. for Non-linear Spectroscopy (Italy) and International Ctr. Of Computational Neurophotonics (Italy) and Univ. of Florence (Italy) 


\section{POSTER SESSION}

$8797 \mathrm{OH} \quad$ Application of a laser trap as a viscometer [8797-27]

J. Cooper, R. Solomon, S. Elrod, T. Barnes, C. Crawford, A. Farone, M. Farone, D. Erenso,

Middle Tennessee State Univ. (United States)

8797 Ol Infrared imaging of fixed-cells through micro-cavity fiber optic scanning microscopy [8797-9]

A. Di Donato, Polytechnic Univ. of Marche (Italy); T. Pietrangelo, Univ. degli studi G.

D'Annunzio Chieti Pescara (Italy); T. Da Ros, Univ. of Trieste (Italy); T. Monti, D. Mencarelli,

G. Venanzoni, A. Morini, M. Farina, Polytechnic Univ. of Marche (Italy)

8797 0J 3D reconstruction methods using line-scanning microscopy with a linear sensor [8797-26] M. P. Macedo, Univ. of Coimbra (Portugal) and ISEC, Instituto Superior de Engenharia de Coimbra (Portugal); C. M. B. A. Correia, Univ. of Coimbra (Portugal)

8797 OK Dynamic control of illumination beam phase profile in a scanning optical microscope [8797-23]

A. Das, Gauhati Univ. (India) and Indian Institute of Technology Guwahati (India);

B. R. Boruah, Indian Institute of Technology Guwahati (India)

$8797 \mathrm{OL}$ Multispot two-photon imaging of calcium waves dynamics in cardial tissue at $16 \mathrm{~Hz}$ frame rate [8797-12]

C. de Mauro, C. A. Cecchetti, D. Alfieri, Light4Tech Firenze S.r.l. (Italy); G. Borile, A. Urbani, M. Mongillo, Univ. of Padova (Italy) and Venetian Institute of Molecular Medicine (Italy); F. S. Pavone, Univ. of Florence (Italy)

8797 OM Effect of stretching DNA on lac Repressor 1D-diffusion revealed by the combination of single-molecule localization and manipulation [8797-16]

G. Belcastro, C. Mónico, LENS, European Lab. for Non-linear Spectroscopy (Italy); M. Capitanio, F. Vanzi, LENS, European Lab. for Non-linear Spectroscopy (Italy) and Univ. of Florence (Italy); F. S. Pavone, LENS, European Lab. for Non-linear Spectroscopy (Italy) and Univ. of Florence (Italy) and National Institute of Optics, National Research Council (Italy) and International Ctr. Of Computational Neurophotonics (Italy)

Author Index 


\title{
Conference Committee
}

\author{
General Chairs
}

Irene Georgakoudi, Tufts University (United States)

Peter Andersen, Technical University of Denmark (Denmark)

Programme Chairs

Jürgen Popp, Friedrich-Schiller Universität Jena (Germany)

Andreas Hielscher, Columbia University (United States)

Conference Chairs

Emmanuel Beaurepaire, Ecole Polytechnique, CNRS (France)

Peter T. C. So, Massachusetts Institute of Technology (United States)

Conference Programme Committee

Claude Boccara, ESPCI ParisTech (France)

Paul J. Campagnola, University of Wisconsin-Madison (United States)

Kishan Dholakia, University of St. Andrews (United Kingdom)

Chen Dong, National Taiwan University (Taiwan)

Paul French, Imperial College London (United Kingdom)

Irene Georgakoudi, Tufts University (United States)

Rainer Heintzmann, Institute of Physical Chemistry (Germany)

Jan Huisken, Max-Planck-Institute of Molecular Cell Biology and Genetics (Germany)

Jerome Mertz, Boston University (United States)

Francesco Saverio Pavone, European Laboratory for Non-linear

Spectroscopy (Italy)

Charles Lin, Massachusetts General Hospital (United States)

Yaron Silberberg, Weizmann Institute of Science (Israel)

Ernst Stelzer, European Molecular Biology Laboratory Heidelberg

(Germany)

Vinod Subramaniam, University of Twente (Netherlands)

\section{Session Chairs}

Biomedical Applications I

Marie-Claire Schanne-Klein, Ecole Polytechnique (France)

Fluorescence I

Peter T. C. So, Massachusetts Institute of Technology (United States)

SHG/THG/CARS/SRS I

Emmanuel Beaurepaire, Ecole Polytechnique, CNRS (France) 
Fluorescence II

Irene Georgakoudi, Tufts University (United States)

Phase I

Gabriel Popescu, University of Illinois at Urbana-Champaign (United States)

Optical Metrology I: Joint Session with Optical Metrology

Pietro Ferraro, Instituto Nazionale di Ottica, CNR (France)

SHG/THG/CARS/SRS ॥

Pablo Loza-Alvarez, ICFO-The Institute of Photonic Sciences (France)

Biomedical Applications II

Peter T. C. So, Massachusetts Institute of Technology (United States)

Phase II

Peter T. C. So, Massachusetts Institute of Technology (United States)

Poster Session

Jürgen Popp, Friedrich-Schiller Universität Jena (Germany) 